\title{
Understanding the Persistence of Occupational Sex Segregation in German Labour Markets: How Gender Attitudes Shape Young Women's Occupational Aspirations
}

\section{Jenny Chesters ${ }^{1}[0$}

Received: 8 July 2021 / Revised: 16 November 2021 / Accepted: 18 November 2021 /

Published online: 17 February 2022

(C) The Author(s) 2022

\begin{abstract}
The persistence of occupational sex segregation is a global phenomenon that relegates women into lower paid, lower status jobs. Understanding why young women apparently choose such jobs is integral to reversing decades of economic inequality related to employment. The strength of the association between the education system and labour market as well as high levels of occupational sex segregation makes Germany an interesting case to study. Using data from the National Education Panel Study (NEPS) Starting Cohort 4 data, I examine whether the occupational aspirations of female secondary school students are related to family characteristics and/ or attitudes to gender roles. The results indicate that girls with fathers employed in male-dominated occupations hold more conservative gender attitudes than their peers with fathers employed in gender-neutral occupations. Girls with more conservative gender attitudes are more likely to hold aspirations for jobs in femaledominated occupations. These findings suggest that despite growth in gender-neutral knowledge-based industries, the socialisation of young women, particularly with regard to attitudes to appropriate roles for women, continues to influence occupational aspirations.
\end{abstract}

Keywords Gender attitudes · Aspirations · Germany · NEPS

\section{Introduction}

The persistence of occupational sex segregation is a global phenomenon that defies the predictions of rational choice theories. Despite being more likely than men to have high levels of education, women continue to be concentrated in

Jenny Chesters

jenny.chesters@unimelb.edu.au

1 Melbourne Graduate School of Education, The University of Melbourne, Melbourne, Victoria, Australia 
female-dominated occupations characterised by lower levels of status and earnings. Understanding this trend requires an examination of how occupational sex segregation in the labour market intersects with women's attitudes to gender roles. Although the expansion of the service sector has increased levels of female employment, it has exacerbated the segregation of men and women into different occupations and done little to alleviate the secondary nature of women's employment. The service sector is polarised into high skill and low skill jobs (Blackburn et al. 2002) which require attributes stereotypically designated as female such as caring and nurturing (Anker 1997; Charles and Grusky 2004; Estevez-Abe 2005). Furthermore, the service sector is more amenable to part-time employment, allowing women to combine their family responsibilities with their need to earn an income. As Haasler (2014) notes, in Germany, the persistence of the male breadwinner model whereby the male partner earns the primary income and the female partner is either a secondary earner or full-time homemaker, combined with entrenched occupational sex segregation, contributes to women's economic disadvantage.

The reproduction of gender is embedded within the education system and the labour market ensuring that women's employment is subject to constraints in terms of their access to vocational training, promotions and high incomes (Haasler and Gottschall 2015). The decision to undertake pathways that lead to employment in female-dominated occupations is inextricably tied to attitudes to gender roles and, therefore, the process of socialisation. Attitudes to gender roles develop during the process of socialisation that begins within the family and is developed through school and community experiences during childhood and adolescence. Through socialisation, children internalise the expectations of their parents and learn to behave in ways that are considered appropriate for their gender (Carlson and Knoester 2011; Cemalcilar et al. 2019; Charles and Grusky 2004).

In this article, I examine the associations between family characteristics and girl's attitudes to gender roles and occupational aspirations drawing on data from the German National Education Panel Study (NEPS). This study builds upon previous research by examining the associations between socialisation, the development of attitudes to gender roles and occupational aspirations of female secondary school students. Previously, I examined associations between gender attitudes and occupational aspirations of male secondary school students (Chesters 2021). Germany provides an interesting setting for this study due to the strong links between the education system and labour market which continues to be highly segregated according to sex. The three research questions guiding the analyses are (1) How do gender attitudes vary according to family characteristics?; (2) What is the association between gender attitudes and occupational aspirations?; (3) What is the association between parents' occupations and student's occupational aspirations? The remainder of this article is structured as follows. After providing a brief overview of the links between the German education system and labour market, the literature review presents a discussion of occupational sex segregation and gender theories. I introduce the data and analytical strategy in the 'Methods' section and then present the results of the analyses and the discussion of the findings. 


\section{Context}

The changing nature of labour markets due to technological innovations has generated new jobs and occupations, particularly in the services sector. Jobs in the services sector are either highly paid, highly skilled professional jobs in health, education and social support or low-paid, unskilled jobs in hospitality and retail (Blackburn et al. 2002). According to Haasler and Gottschall (2015), the German labour market has become more segregated in terms of both skills and gender in recent decades as the new employment opportunities generated by technological innovations and the marketization of care were rapidly sex-typed into male or female occupations.

The polarisation of the labour market into jobs requiring high levels of technological skills or occupations requiring non-credentialed soft skills (Kalleberg 2011; Leuze and Strauss 2016) has increased the importance of the education system as a sorting mechanism for the labour market, particularly in Germany. The German education system focuses on providing students with opportunities to develop occupation specific credentials. Vocational specialisation occurs relatively early in the school career (Blossfeld 1990; Bosch and Charest 2008; Brzinsky-Fay and Solga 2016; Ebner 2015) when children are allocated to one of three secondary school tracks in grade 5: preparation for university and professional occupations (Gymnasium); preparation for high-skilled non-professional occupations (Realschule); and preparation for skilled manual occupations (Hauptschule) (Glaesser and Cooper 2011). Although in most German states, students allocated to different tracks attend different schools, in some states secondary students may attend comprehensive schools which offer all three tracks (Glaesser and Cooper 2011).

In Germany, the structure of the education system ensures that initial occupational aspirations have a strong effect on labour market opportunities (Malin and Jacob 2019) with around two thirds of students undertaking vocational training (Bosch and Charest 2008) either through the completion of dual vocational programs (firm-based apprenticeships) or a school-based education and training program. Firm-based apprenticeships combine practical experience in the workplace with theoretical knowledge in the classroom and provide young people with the credentials for employment in the manufacturing, commercial, retail and administration sectors (Blossfeld et al. 2011; Bosch and Charest 2008; Brzinsky-Fay and Solga 2016; Ebner 2015; Haasler and Gottschall 2015). Students who complete school-based vocational education and training programs earn nationally recognised certificates for employment in personal service occupations such as nurses and social workers (Blossfeld et al. 2011; Brzinsky-Fay and Solga 2016; Haasler and Gottschall 2015; Jacob et al. 2013).

The division between school-based vocational programs and dual vocational programs tends to segregate young people according to sex preparing them for sex-segregated occupations (Blossfeld et al. 2015; Haasler 2014; Haasler and Gottschall 2015), thus ensuring that occupational stratification according to sex persists over time (Haasler 2014; Haasler and Gottschall 2015; Hadjar and 
Aeschlimann 2015). Firm-based apprentices are regarded as employees and are therefore paid during their training whereas as school-based trainees are not paid (Malin and Jacob 2019). Thus, the seeds of a lifetime of economic inequality are sown during secondary school. Girls who have internalised gender stereotypes are less likely than their more egalitarian peers to select vocational paths perceived as being stereotypically male (Hadjar and Aeschlimann 2015) despite monetary incentives.

\section{Occupational Sex Segregation}

Occupational sex segregation occurs when men are concentrated in particular jobs and occupations and women are concentrated in different jobs and occupations (Gauchat et al. 2012). Sex segregation can be vertical (men are employed in higher status occupations than women) or horizontal (men and women are employed in different occupations, the manual/non-manual divide) (Blackburn et al. 2001; Charles 2003; Charles and Grusky 2004; Jarman et al. 2012). According to Charles (2003), the cultural belief that men are more worthy of high-status jobs and more capable of exercising authority underpins vertical sex segregation and exacerbates inequality in earnings (see also Jarman et al. 2012). Horizontal sex segregation is the outcome of gender stereotypes which assume that occupations requiring soft skills such as nurturing and caring are more suitable for women whereas occupations requiring physical strength or technical abilities are more suitable for men (Anker 1997; Charles and Grusky 2004; Estevez-Abe 2005). As Hadjar and Aeschlimann (2015) note, occupational sex segregation reinforces stereotypes based on beliefs that men and women have different 'natural' abilities and therefore economic inequality is a 'natural', rather than socially constructed, outcome of engagement with labour markets.

Occupational sex segregation exacerbates inequality by channelling women into low status, low-paid insecure work in female-dominated occupations (Gauchat et al. 2012; Leuze and Strauss 2016). The undervaluation of female-dominated occupations is embedded in institutions such as formal wage determination processes (Koskinen Sandberg et al. 2018). According to Leuze and Strauss (2016), as the female share within an occupation increases, wages decline (see also England et al. 2007; Garcia-Mainar et al. 2018). Consequently, male-dominated occupations attract relatively higher levels of pay, more employment-related benefits and increased opportunities for promotions (Charles 1992; Kmec 2005). The concentration of women in the service sector (Jacob et al. 2013) and, in particular, in low skilled jobs within this sector has given rise to what Abrantes and Abrantes (2014: 379) term 'a post-industrial proletariat' which is particularly vulnerable to exploitation.

\section{Theoretical Perspectives}

To explain occupational sex segregation, researchers generally draw on explanations based on gender theories which focus on either biological differences or gender ideologies (Webb 2009). As Anker (1997) points out, gender theories explain 
how gender stereotypes and cultural restrictions establish what types of occupations are suitable for women. Gender stereotypes are shared understandings of how men and women should behave and have a negative impact on the way women's work is evaluated and on the expectations of how women work (Correll 2017). Believing that men and women have different traits and are suited to different roles is a social construction that perpetuates occupational sex segregation (Cech 2013). For example, the ability to care and nurture is regarded as a feminine trait, and the ability to solve technical problems is regarded as a masculine trait (Charles and Grusky 2004; Lueptow et al. 2001; Ridgeway and Correll 2004; Ridgeway et al. 2009). Consequently, care occupations are regarded as being suitable for women, and technical occupations are regarded as being suitable for men.

The main two theoretical explanations of occupational sex segregation are gender essentialism and male primacy. Gender essentialism posits that 'women are more competent than men in service, nurturance and social interaction' and male primacy posits that 'men are more status worthy than women and accordingly more appropriate for positions of authority and domination' (Charles and Grusky 2004: 7). From a related perspective, gender is regarded as an accomplishment that is produced and reproduced in everyday interactions and activities (West and Fenstermaker 1993; West and Zimmerman 1987). Individuals 'produce behavioural displays' appropriate to their gender (West and Zimmerman 1987:139). In other words, gender is a performance, 'a routine accomplishment in social interactions' (Nentwich and Kelan 2014: 122). For men doing gender is associated with being dominant, whereas for women, doing gender is associated with doing deference. As Cech (2013: 756) argues, 'men and women make explicitly gendered decisions' in every dimension of social life.

According to Ridgeway and Correll (2004), how one does gender is prescribed by gender stereotypes (see also Ridgeway et al. 2009). Women with stereotypical attitudes to gender roles prefer jobs in female-dominated occupations and men with stereotypical attitudes to gender roles prefer jobs in male-dominated occupations (Estevez-Abe 2006). Therefore, occupational sex segregation provides women (and men) with traditional gender role belief opportunities to enact traditional roles (Cech 2013). In other words, working in a female-dominated occupation reaffirms the feminine identity of a woman with stereotypical gender attitudes. Individuals holding egalitarian attitudes to gender roles are more likely than those with stereotypical gender attitudes to seek employment in gender-neutral occupations (those with similar proportions of men and women) or atypical occupations (e.g. women working in male-dominated occupations such as engineering).

Socialisation plays an integral role in the development of attitudes to gender roles and therefore in the perpetuation of occupational sex segregation. During the process of socialisation, children acquire values, attitudes and behaviours through their exposure to the cultural beliefs and values of their families and social networks (Carlson and Knoester 2011; Cemalcilar et al. 2019). The internalization of gendered expectations surfaces as sex-typed occupational aspirations (Charles and Grusky 2004). As children develop their own identity and prepare for particular roles in their adult life, they adapt the behaviours modelled by their parents (Lueptow et al. 2001; Reskin 1993). The process of socialisation that prepares children for adult roles occurs initially in the family and is 
then reinforced by schools and the community more generally. By modelling and reinforcing gender-appropriate behaviour, families and schools may discourage young women from considering gender-neutral occupations. Therefore, depending on their levels of education, young women with traditional attitudes to gender roles may face a lifetime of economic disadvantage.

Although there is a plethora of research examining the associations between attitudes to gender roles and occupational sex segregation, few researchers have focused on the associations between socialisation, the development of attitudes to gender roles and occupational aspirations of female secondary school students. Although Chesters (2021) examined these associations for male secondary school students, the gendered nature of these associations and the implications for employment careers differ for young men and young women. Therefore, this paper seeks to fill a gap in our understanding of how young women are socialised for their post-school lives. To answer the three research questions, a series of hypotheses were developed:

H1a: Father's education is associated with daughter's attitudes to gender roles. The expectation is that daughters who have fathers with higher levels of education will have less traditional attitudes to gender roles than their peers who have fathers with low levels of education.

H1b: Mother's education is associated with daughter's attitudes to gender roles. The expectation is that daughters who have mothers with higher levels of education will have less traditional attitudes to gender roles than their peers who have mothers with low levels of education.

H1c: Father's job type is associated with daughter's attitudes to gender roles. The expectation is that daughters who have fathers who are employed in gender-neutral or gender atypical jobs will have less traditional attitudes to gender roles than their peers with fathers who are employed in gender typical jobs.

H1d: Mother's job type is associated with daughter's attitudes to gender roles. The expectation is that daughters who have mothers who are employed in gender-neutral or gender atypical jobs will have less traditional attitudes to gender roles than their peers with mothers who are employed in gender typical jobs.

H2: Attitudes to gender roles are associated with occupational aspirations. The expectation is that girls with traditional attitudes to gender roles are more likely to hold aspirations for gender typical jobs than for gender-neutral or gender atypical jobs.

H3a: Father's job type is associated with daughter's occupational aspirations. The expectation is that girls who have fathers in gender typical jobs will be less likely to hold aspirations for gender-neutral or gender atypical jobs than to hold aspirations for gender typical jobs.

H3b: Mother's job type is associated with daughter's occupational aspirations. The expectation is that girls who have mothers in gender typical jobs will be less likely to hold aspirations for gender-neutral or gender atypical jobs than to hold aspirations for gender typical jobs. 


\section{Methods}

\section{Data}

To test the hypotheses, I conduct analyses of the first eight waves of the NEPS Starting Cohort 4 data. The NEPS Starting Cohort 4 participants were 9 th graders attending regular schools in 2010. They were selected via stratified cluster sampling and were representative of all 9th graders in Germany. Initially, 545 schools were selected and then all students in one or two 9th grade classes in each of the schools were invited to participate (Skopek et al. 2013). In some years, participants were surveyed twice, consequently between 2010 and 2015, and eight waves of data were collected. The variables of interest were collected in different waves; therefore, I combine the relevant variables across the eight waves of data to create a new dataset that includes all of the variables of interest. For example, occupational aspirations were measured in the year before graduation from secondary school: the 9th grade for Hauptschule students; the 10th grade for Realschule students; and the 12th/13th grade for Gymnasium students.

\section{Variables}

To test hypotheses $\mathrm{H} 1 \mathrm{a}-\mathrm{H} 1 \mathrm{~d}$, the outcome variable is attitude to gender roles. Attitudes to gender roles are closely related to occupational aspirations because as Cech (2013) argues, women with stereotypical attitudes to gender roles are more likely than their peers with less traditional attitudes to enter female-dominated occupations. Attitudes to gender roles were measured by a series of five questions in wave $3(2011 / 2012)$ :

(1) Women and men should have the same household obligations.

(2) Women can use technical devices just as well as men.

(3) Women should be able to learn the same professions as men.

(4) Women and men should be equally represented in politics.

(5) Man's job to earn money.

The answer options on the 5-point Likert scale ranged from completely disagree to completely agree. The first four questions were reverse coded so that the completely disagree category had the highest value. I developed the gender attitude index by estimating the mean of the responses to these questions. Although, in this paper, the focus is on female students, the index was estimated using the responses from all students. The Cronbach's alpha for this index is 0.7711 , indicating that it is internally coherent, that is, the questions are tapping different dimensions of the same underlying concept. The gender attitude index ranges from 1 (less traditional) to 5 (very traditional) and has a mean of 2.08 with a standard deviation of 0.88 . On average, females were less traditional than males: the mean for females is 1.64 , whereas the mean for males is 2.55 . 
The four key explanatory variables are father's education and occupation and mother's education and occupation. The father's and mother's education variables have four categories: no educational qualification; secondary level 1 qualification; secondary technical qualification; and tertiary qualification. Father's and mother's occupation variables have four categories: not employed; male job; gender-neutral job; and female job. The NEPS team coded the occupation variables according to the German Classification of Occupations 1988 (https://www.klassifikationsserver. de/klassService/jsp/common/url.jsf?variant=kldb1988\&lang=EN). Based on data supplied by the Federal Employment Agency (Germany), jobs were coded into three categories: jobs in which less than $31 \%$ of the workers were female were coded as male jobs; jobs in which at least $70 \%$ of the workers were female were coded as female jobs; all other jobs are coded as gender-neutral jobs (see also Hagglund and Bachmann 2017; Kmec 2005; Malin and Jacob 2019). I also include dummy variables to indicate if there was no father (mother) living in the family home.

I include two control variables captured in wave 1 when the students were in the 9th grade: migrant status and family type. The migrant status variable has two categories: German (student and both parents were born in Germany) and migrant (at least one parent was not born in Germany). Previous research indicates that migrant status is an important explanatory variable for differences in occupational aspirations (Chesters 2015; Chesters 2021).The family type variable has four categories: two parents; mother only; father only; and other. As Carlson and Knoester (2011) note, in single-parent families there is only one role model which may affect the development of attitudes to gender roles.

To test hypothesis $\mathrm{H} 2$, the outcome variable, occupational aspirations, is derived from a question about the student's preferred career. I divide career aspirations into three job type categories: male; gender-neutral and female using the same strategy as was used for the coding of parents' occupations. To test hypotheses $\mathrm{H} 3 \mathrm{a}$ and H3b, the outcome variable is occupational aspirations; the key explanatory variable is father's [mother's] job type; and the control variables are migrant status and attitudes to gender roles. Previous research indicates that mother's and father's employment status and occupations are important factors shaping children's attitudes to gender roles as well as their occupational aspirations (McGinn et al. 2019).

Cases with missing values on key variables were dropped from the analyses leaving a sample of 2530 cases. The descriptive statistics of these variables are presented in Table 6 in the Appendix. Table 7 in the Appendix presents the mean values on the gender attitude index according to selected characteristics.

\section{Analytical Strategy}

Given that the analyses are conducted using cross-sectional data from the new data set created for this paper, the models are not designed to infer causality. The models are seeking to identify correlations between the outcome variables and the explanatory variables.

To test hypotheses H1a-H1d, I conduct a series of linear regressions to estimate regression coefficients. Regression coefficients represent the average change in 
gender attitudes that can be attributed to change in each of the explanatory variables, net of the other explanatory variables. In the first model, the coefficient for each category of father's education on daughter's attitudes to gender roles is net of migrant status. In the second model, the coefficient for each category of mother's education on daughter's attitudes to gender roles is net of migrant status. Similar regressions are run to estimate the effects of father's and mother's job type on daughter's attitudes to gender roles.

To test hypothesis H2, I conduct multinomial logistic regression analysis. Multinomial logistic regression analysis estimates the relative risk ratios for each of the two categories not selected as the reference category. I select holding aspirations for a female-type job as the reference category and compare whether girls holding more traditional attitudes are more or less likely to hold aspirations for gender-neutral or male-type jobs, net of migrant status and family type. Due to small numbers in the 'father only' and 'other' categories of the family type variable, I combine these two categories; therefore, the family type variable distinguishes between having two parents, mother only and other.

To test hypotheses $\mathrm{H} 3 \mathrm{a}$ and $\mathrm{H} 3 \mathrm{~b}$, I conduct multinomial logistic regression analysis to estimate the relative risk ratios for holding aspirations for female-type jobs compared to holding aspirations for gender-neutral or male-type jobs. The models estimate the likelihood of holding aspirations for (1) a gender-neutral job and (2) a male-type job relative to holding aspirations for a female-type job.

\section{Results}

Table 1 presents the results of the linear regression models examining the associations between father's and mother's education and female student's attitudes to gender roles. The results for Model 1 indicate that father's education was not associated with daughter's attitudes to gender roles, net of migrant status. Female students with mothers who had secondary technical qualifications held less traditional attitudes to gender roles than female students with low-educated mothers, net of migrant status. Female students from migrant backgrounds held more traditional attitudes than students born in Germany with German parents.

Table 2 presents the results of the models examining the association between attitudes to gender roles and father's and mother's job type. The results indicate that neither father's job type nor mother's job type is associated with attitudes to gender roles, net of migrant status.

The results of the model examining the associations between attitudes to gender roles and occupational aspirations are presented in Table 3. Female students with more traditional attitudes were less likely to want a gender-neutral job or a male job relative to wanting a female job, net of migrant status and family type.

After controlling for gender attitudes and migrant status, female students with fathers employed in gender-neutral jobs were more likely than female students with fathers employed in male jobs to want a gender-neutral job relative to wanting a female job-see Table 4. Being a migrant was also associated with holding 
Table 1 Association between gender attitudes and parents' education

\begin{tabular}{|c|c|c|c|c|}
\hline \multirow[b]{2}{*}{ Gender attitudes } & \multicolumn{2}{|l|}{ Model 1} & \multicolumn{2}{|l|}{ Model 2} \\
\hline & Coef. & Std. Err. & Coef. & Std. Err. \\
\hline \multicolumn{5}{|c|}{ Migrant status (ref.=German) } \\
\hline Migrant & $0.16 * * *$ & 0.03 & $0.16^{* * * *}$ & 0.03 \\
\hline \multicolumn{5}{|c|}{ Father's education (ref. $=$ no qual.) } \\
\hline Secondary level 1 & -0.01 & 0.03 & & \\
\hline Secondary technical & -0.05 & 0.03 & & \\
\hline Tertiary qualification & -0.06 & 0.04 & & \\
\hline No Father & -0.03 & 0.06 & & \\
\hline \multicolumn{5}{|c|}{ Mother's education (ref.= no qual.) } \\
\hline Secondary level 1 & & & -0.05 & 0.03 \\
\hline Secondary technical & & & $-0.10 * * *$ & 0.03 \\
\hline Tertiary qualification & & & -0.07 & 0.04 \\
\hline No Mother & & & -0.08 & 0.19 \\
\hline Constant & $1.60 * * *$ & 0.02 & $1.62 * * *$ & 0.03 \\
\hline $\mathrm{n}=$ & 2530 & & 2530 & \\
\hline Adj R-square & 0.0132 & & 0.0153 & \\
\hline
\end{tabular}

$* * * p<0.001$

aspirations for a gender-neutral job rather than a female-type job. On the other

Table 2 Association between gender attitudes and parents' job type

\begin{tabular}{|c|c|c|c|c|}
\hline \multirow[b]{2}{*}{ Gender attitudes } & \multicolumn{2}{|l|}{ Model 1} & \multicolumn{2}{|l|}{ Model 2} \\
\hline & Coef. & Std. Err. & Coef. & Std. Err. \\
\hline \multicolumn{5}{|c|}{ Migrant status (ref.=German) } \\
\hline Migrant & $0.16^{* *}$ & 0.03 & $0.16 * *$ & 0.03 \\
\hline \multicolumn{5}{|c|}{$\begin{array}{l}\text { Father job }(\text { ref. }=\text { male } \\
\text { job })\end{array}$} \\
\hline Not employed & -0.06 & 0.07 & & \\
\hline Neutral job & -0.02 & 0.03 & & \\
\hline Female job & 0.01 & 0.04 & & \\
\hline No father & -0.01 & 0.05 & & \\
\hline \multicolumn{5}{|c|}{ Mother job (ref.=female job) } \\
\hline Not employed & & & 0.06 & 0.04 \\
\hline Neutral job & & & 0.07 & 0.04 \\
\hline Male job & & & -0.01 & 0.03 \\
\hline No mother & & & 0.16 & 0.13 \\
\hline Constant & $1.58 * * *$ & 0.02 & $1.56^{* * *}$ & 0.02 \\
\hline$n=$ & 2530 & & 2530 & \\
\hline Adj R-square & 0.0119 & & 0.0142 & \\
\hline
\end{tabular}

$* * * p<0.001 ; * * p<0.01$ 
Table 3 Multinomial logistic regression of gender attitudes on female students' occupational aspirations

\begin{tabular}{|c|c|c|c|c|}
\hline & \multicolumn{2}{|c|}{$\begin{array}{l}\text { Gender-neutral V } \\
\text { female job }\end{array}$} & \multicolumn{2}{|c|}{$\begin{array}{l}\text { Male job V female } \\
\text { job }\end{array}$} \\
\hline & RRR & Std. err. & RRR & Std. err. \\
\hline Gender attitudes & $0.71 * * *$ & 0.09 & $0.74 * * *$ & 0.06 \\
\hline \multicolumn{5}{|c|}{ Migrant status (ref.=German) } \\
\hline Migrant & 1.14 & 0.21 & 1.23 & 0.14 \\
\hline \multicolumn{5}{|c|}{ Family type (ref.=two parents) } \\
\hline Mother only & 0.78 & 0.23 & 1.02 & 0.16 \\
\hline Other & 0.78 & 0.49 & 0.47 & 0.21 \\
\hline Constant & $0.38 * * *$ & 0.08 & $1.51 * *$ & 0.20 \\
\hline$n=$ & 2530 & & & \\
\hline Pseudo R-square & 0.0049 & & & \\
\hline
\end{tabular}

hand, those with more traditional attitudes were less likely to hold aspirations for gender-neutral jobs.

The results presented in Table 5 show that after controlling for gender attitudes and migrant status, female students with mothers who were employed in male jobs were more likely than female students with mothers employed in female jobs to want a male job relative to wanting a female job. Female students with mothers employed in gender-neutral jobs were more likely than female students with mothers employed in female jobs to want a gender-neutral job relative to wanting a female job.

Table 4 Multinomial logistic regression of father's job type on female students' occupational aspirations

\begin{tabular}{|c|c|c|c|c|}
\hline & \multicolumn{2}{|c|}{ Male job V female job } & \multicolumn{2}{|c|}{$\begin{array}{l}\text { Gender-neutral job } \\
\text { V female job }\end{array}$} \\
\hline & RRR & Std. err. & RRR & Std. err. \\
\hline \multicolumn{5}{|c|}{ Father job (ref.=male job) } \\
\hline Not employed & 0.63 & 0.28 & 0.72 & 0.19 \\
\hline Neutral job & 0.84 & 0.15 & $1.32 * *$ & 0.13 \\
\hline Female job & 0.69 & 0.17 & 1.03 & 0.15 \\
\hline No father & 0.67 & 0.25 & 0.86 & 0.18 \\
\hline \multicolumn{5}{|c|}{ Migrant status (ref.=German) } \\
\hline Migrant & 1.15 & 0.21 & $1.27 *$ & 0.14 \\
\hline Gender attitudes & $0.71 *$ & 0.10 & $0.74 * * *$ & 0.06 \\
\hline Constant & $0.41 * * *$ & 0.09 & $1.41 *$ & 0.19 \\
\hline$n=$ & 2530 & & & \\
\hline Pseudo R-square & 0.0076 & & & \\
\hline
\end{tabular}


Table 5 Multinomial logistic regression of mother's job type on female students' occupational aspirations

\begin{tabular}{|c|c|c|c|c|}
\hline & \multicolumn{2}{|c|}{ Male job V female job } & \multicolumn{2}{|c|}{$\begin{array}{l}\text { Gender-neutral job } \\
\text { V female job }\end{array}$} \\
\hline & RRR & Std. err. & RRR & Std. err. \\
\hline \multicolumn{5}{|c|}{ Mother job (ref.=female job) } \\
\hline Not employed & 1.11 & 0.27 & 0.90 & 0.14 \\
\hline Male job & $1.68 *$ & 0.40 & 1.23 & 0.20 \\
\hline Neutral job & 1.36 & 0.24 & $1.36^{* * *}$ & 0.15 \\
\hline No mother & 1.19 & 0.94 & 0.75 & 0.40 \\
\hline \multicolumn{5}{|c|}{ Migrant status (ref.=German) } \\
\hline Migrant & 1.14 & 0.21 & $1.25 *$ & 0.14 \\
\hline Gender attitudes & $0.71 *$ & 0.10 & $0.74 * * *$ & 0.06 \\
\hline Constant & $0.33 * * *$ & 0.08 & $1.39 * * *$ & 0.19 \\
\hline$n=$ & 2530 & & & \\
\hline Pseudo R-square & 0.0072 & & & \\
\hline
\end{tabular}

$* * * p<0.001 ; * * p<0.01 ; * p<0.05$

\section{Discussion}

This paper examined the associations between family characteristics, attitudes to gender roles and occupational aspirations for one cohort of German female secondary school students. To answer the three research questions posed in the 'Introduction' section of this article, a series of hypotheses were formulated and tested. Four hypotheses were formulated to answer the first research question 'How do gender attitudes vary according to family characteristics? The results presented here show that father's education is not associated with daughter's attitudes to gender roles; thus Hypothesis 1a is not supported. Support for Hypothesis 1b is weak. Girls who had mothers with a secondary technical level of education held slightly less traditional attitudes to gender roles $(-0.10$ on the scale of $1-5)$; however, having a mother with a tertiary level qualification was not associated with attitudes to gender roles. These findings contrast those of Chesters (2021) which showed that both father's and mother's level of education was associated with son's attitudes to gender roles indicating that the effect of parental education is gendered.

The findings presented in Table 2 indicate that there is no support for Hypothesis 1c and Hypothesis 1d. Neither father's nor mother's job type was associated with daughter's attitudes to gender roles. Furthermore, having a mother who was not employed was not associated with attitudes to gender roles. This finding contrasts with the results of previous research which indicates that having an employed mother is associated with holding less traditional attitudes to gender roles (Chesters 2009; Davis and Greenstein 2009; McGinn et al. 2019). According to Chesters' (2021) analysis, boy's attitudes to gender roles were associated with the occupations of both their father and mother, again indicating that the effects of family background characteristics are gendered.

Strikingly, there is a strong and persistent association between migrant status and attitudes to gender roles with female migrant students holding more traditional 
attitudes than female non-migrant students. In these analyses, the migrant status variable did not distinguish between first- and second-generation migrants or country of origin. This presents an opportunity for future research. Understanding why migrant students are more traditional may provide a partial explanation for the persistence of economic disadvantage experienced by some groups of migrants.

The results of the analysis to test Hypothesis $\mathrm{H} 2$ and, thus, answer the second research question 'What is the association between gender attitudes and occupational aspirations?' indicate that holding more traditional aspirations is associated with being less likely to hold aspirations for a gender-neutral or male-type job relative to holding aspirations for female-type jobs. Therefore, hypothesis $\mathrm{H} 2$ is supported. In other words, female students with more traditional attitudes to gender roles want jobs that allow them to 'do gender' (West and Zimmerman 1987). Females do gender by behaving in ways that reaffirm their femininity. Cech (2013: 756) argues that gender beliefs influence women's occupational preferences through their desire enact traditional gender roles; perceptions that some jobs are more suitable for men and others are more suitable for women; and their beliefs that men and women have different 'natural' abilities and talents. Chesters (2021) found that gender attitudes were also associated with occupational aspirations for boys: those with traditional attitudes to gender roles were more likely to hold aspirations for male-typed occupations than their more egalitarian peers. These results align with those of Hadjar and Aeschlimann (2015) who found that girls who had internalised gender stereotypes were less likely to pursue vocational education and training for occupations perceived as being more suitable for boys. Earlier research conducted by Estevez-Abe (2006) also indicated that there was a strong link between attitudes to gender roles and occupational aspirations.

To answer the final research question, 'What is the association between parents' occupations and student's occupational aspirations?', models were designed to test hypothesis $\mathrm{H} 3 \mathrm{a}$ and hypothesis $\mathrm{H} 3 \mathrm{~b}$. The results presented in Table 4 indicate that hypothesis $\mathrm{H} 3 \mathrm{a}$ is partially supported in that girls who had fathers employed in gender-neutral jobs were more likely to hold aspirations for gender-neutral jobs relative to holding aspirations for female jobs. However, father's job type was not associated with the likelihood of holding aspirations for male jobs relative to holding aspirations for female jobs. Hypothesis $\mathrm{H} 3 \mathrm{~b}$ is supported with the results presented in Table 5 showing that girls who had mothers working in male-type jobs were more likely to hold aspirations for male jobs relative to holding aspirations for female jobs and that girls with mothers employed in gender-neutral jobs were more likely to hold aspirations for gender-neutral jobs relative to holding aspirations for female jobs. In other words, girls exposed to less traditional gender norms at home because their parents undermined gender stereotypes by modelling gender atypical behaviour were more likely to aspire to gender-neutral or gender atypical jobs. On the other hand, girls growing up in more traditional households were more likely to hold aspirations for female-type jobs which are typically of lower status and are lower paid perpetuating the economic disadvantage associated with being female. In other words, due to their inability to separate their desire to reaffirm their femininity from their occupation and/ or employment status, females with traditional attitudes to gender roles are less likely to achieve economic independence. As West 
and Zimmerman (1987) point out, holding traditional gender attitudes is strongly associated with preferring jobs that allow one to 'do gender'. Women 'do gender' by behaving in ways that reaffirm their femininity.

Summing up, gender theories posit that the persistence of occupational sex segregation is due to the enduring influence of gender stereotypes based on beliefs that women are more suited to jobs requiring caring and nurturing and men are more suited to jobs requiring technical abilities. Although professional occupations in the service sectors tend to be regarded as being gender-neutral, jobs requiring low level skills tend to be regarded as either male jobs or female jobs. Occupations with a relatively high proportion of female workers are generally characterised by low levels of pay, on-the-job training opportunities and opportunities for promotion (Charles 1992; Kmec 2005). Therefore, holding aspirations for female-type jobs, those in which at least $70 \%$ of the workers are female, may translate into a lifetime of economic disadvantage.

As with all empirical analysis, there are some limitations that need to be noted. Firstly, by grouping occupational aspirations into three categories (male jobs, female jobs and gender-neutral jobs), it is not possible to differentiate between horizontal and vertical sex segregation. Secondly, the occupational aspirations of male students were not examined here-please refer to Chesters (2021) for an examination of family characteristics, attitudes to gender roles and occupational aspirations of male secondary school students in Germany. To alleviate women's disadvantage in the labour market, more occupations need to become gender-neutral, that is, where the proportions of men and women working in a particular occupation are more equal. This will require girls to hold aspirations for, and have opportunities to engage in, male-dominated occupations. Given the longitudinal nature of the NEPS project, future research could examine employment outcomes to examine whether occupational aspirations during secondary school are realised later in life. For example, it would be possible to test for a causal relationship between occupation aspirations in the year before leaving secondary school and employment outcomes 10 years after completing secondary school.

\section{Conclusion}

The persistence of sex segregation in the German labour market is strongly tied to the sex segregation of the German secondary school system. By allocating students according to their preferences and aptitude for gendered vocational pathways, secondary education prepares girls who do not choose, or have the option to choose, the academic pathway into university, for a life time of economic inequality. Unlike the firm-based apprenticeships preferred by male students, school-based vocational training is not paid; therefore, from an economic perspective, by choosing a schoolbased program, girls are disadvantaged. This disadvantage follows them throughout their working life as the occupations they are prepared for are female-dominated, 
lower paid and lower status occupations. Young women are encouraged to embark on vocational pathways that will support the persistence of the male breadwinner model whereby men are regarded as the primary earners and women are regarded as secondary earners or homemakers (Haasler 2014).

The strong association between mother's occupation and daughter's occupational aspirations is an indication of the intergenerational transmission of values (Cemalcilar et al. 2019) with mothers holding the key to weakening gender stereotypes by 'doing gender' differently. In other words, by engaging in gender-neutral or male occupations, mothers may be encouraging their daughters to seek other avenues to display their femininity undermining cultural beliefs about gender-appropriate behaviour. However, given that Germany is widely regarded as conservative country, achieving a less-segregated labour market may take several generations (Blossfeld et al. 2015). Social institutions including family, education system and labour market reinforce societal expectations of gender-appropriate behaviours constraining the ability of young women to adopt the gender-neutral behaviours necessary for economic independence. 


\section{Appendix}

Table 6 Descriptive statistics of the variables of interest

\begin{tabular}{lll}
\hline Characteristics & $n=2530$ & $\%$ \\
\hline Migrant status & & \\
German & 2060 & 81 \\
Second generation & 395 & 16 \\
First generation & 75 & 3 \\
Family type & & \\
Two parents & 2326 & 92 \\
Mother only & 176 & 7 \\
Father only & 26 & 1 \\
Other & 2 & 0
\end{tabular}

Father's job type

Not employed

$70 \quad 3$

Male

$1454 \quad 57$

Neutral

633

25

Female

265

10

No father

108

Mother's job type

Not employed

$236 \quad 9$

Male

$211 \quad 8$

Neutral

537

21

Female

1529

60

No Mother

17

Father's education

No qualification

$668 \quad 26$

Secondary Level 1

$851 \quad 34$

Secondary technical

$527 \quad 21$

Tertiary qualification

381

15

No father

103

4

Mother's education

No qualification

$509 \quad 20$

Secondary Level 1

$1141 \quad 45$

Secondary technical

55422

Tertiary qualification

$318 \quad 13$

No mother

8

Job aspiration

\begin{tabular}{lll} 
Female & 1158 & 46 \\
Gender-neutral & 1118 & 44 \\
Male & 254 & 10 \\
\hline
\end{tabular}
6

16
3
92
7
3
57
25
10
4
9
8
21

4


Table 7 Gender attitudes' mean according to selected characteristics

\begin{tabular}{|c|c|c|c|}
\hline Characteristic & Mean & Characteristic & Mean \\
\hline Migrant status & & Family type & \\
\hline German & 1.57 & Two parents & 1.60 \\
\hline Second generation & 1.72 & Mother only & 1.64 \\
\hline First generation & 1.84 & Other & 1.61 \\
\hline Father's education & & Father's job type & \\
\hline No qualification & 1.63 & Not employed & 1.58 \\
\hline Secondary Level 1 & 1.61 & Male & 1.61 \\
\hline Secondary technical & 1.57 & Neutral & 1.59 \\
\hline Tertiary qualification & 1.57 & Female & 1.61 \\
\hline No father & 1.61 & No father & 1.61 \\
\hline Mother's education & & Mother's job type & \\
\hline No qualification & 1.67 & Not employed & 1.67 \\
\hline Secondary Level 1 & 1.60 & Male & 1.66 \\
\hline Secondary technical & 1.55 & Neutral & 1.58 \\
\hline Tertiary qualification & 1.59 & Female & 1.59 \\
\hline No mother & 1.63 & No mother & 1.78 \\
\hline \multicolumn{4}{|l|}{ Job aspiration } \\
\hline Female & 1.55 & & \\
\hline Gender-Neutral & 1.57 & & \\
\hline Male & 1.65 & & \\
\hline
\end{tabular}

Acknowledgements This paper uses data from the National Educational Panel Study (NEPS): Starting Cohort Grade 9, 10.5157/NEPS:SC4:7.0.0. From 2008 to 2013, NEPS data was collected as part of the Framework Program for the Promotion of Empirical Educational Research funded by the German Federal Ministry of Education and Research (BMBF). As of 2014, NEPS is carried out by the Leibniz Institute for Educational Trajectories (LIfBi) at the University of Bamberg in cooperation with a nationwide network.

I would like to thank Ann-Christin Bachmann for sharing her file with the percentages of males in each occupation and for providing comments on an early draft of this paper.

Funding Open Access funding enabled and organized by CAUL and its Member Institutions.

\section{Declaration}

Conflict of Interest Author is a colleague of Associate Professor Hernan Cuervo, the Editor of this journal.

Open Access This article is licensed under a Creative Commons Attribution 4.0 International License, which permits use, sharing, adaptation, distribution and reproduction in any medium or format, as long as you give appropriate credit to the original author(s) and the source, provide a link to the Creative Commons licence, and indicate if changes were made. The images or other third party material in this article are included in the article's Creative Commons licence, unless indicated otherwise in a credit line to the material. If material is not included in the article's Creative Commons licence and your intended use is not permitted by statutory regulation or exceeds the permitted use, you will need to obtain permission directly from the copyright holder. To view a copy of this licence, visit http://creativecommons.org/licen ses/by/4.0/. 


\section{References}

Abrantes P, Abrantes M (2014) Gendering social mobility: a comparative perspective on the nexus of education and class across Europe. Gend Educ 26(4):377-396

Anker R (1997) Theories of occupational segregation by sex: An overview. Int Labour Rev 136(3):315-339

Blackburn R, Brooks B, Jarman J (2001) The vertical dimension of occupational sex-segregation. Work Employ Soc 15(3):511-538

Blackburn R, Browne J, Brooks B, Jarman J (2002) Explaining gender segregation. Br J Sociol 53(4):513-536

Blossfeld H-P (1990) Changes in Educational Careers in the Federal Republic of Germany. Sociol Educ 63(3): 165-177

Blossfeld H-P, Rossbach H-G, von Maurice J (Eds.) (2011) Education as a Lifelong Process -- The German National Educational Panel Study(NEPS). [Special Issue] Zeitschrift fuer Erziehungswissenschaft: 14

Blossfeld H-P, Buccholz S, Dammrich J, Kilpi-Jakonen, Kosyakova Y, Skopek J, Triventi M, Vono de Vilhena D (2015) Gender differences at labor market entry: the effect of changing educational pathways and institutional structures. In: Blossfeld H-P, Skopek J, Triventi M, Buccholz S (eds) In Gender, Education and Employment: An International Comparison of School-to-Work Transitions. Edward Elgar, Cheltenham, pp 3-35

Bosch G, Charest J (2008) Vocational training and the labour market in liberal and coordinated economies. Ind Relat J 39(5):428-447

Brzinsky-Fay C, Solga H (2016) Compressed, postponed, or disadvantaged?. School-to-worktransition patterns and early occupational attainment in West Germany. Res Soc Stratif Mobil 46:21-36

Carlson DL, Knoester C (2011) Family structure and the intergenerational transmission of gender ideology. J Fam Issues 32(6):709-734

Cech EA (2013) The self-expressive edge of occupational sex segregation. Am J Sociol 119(3):747-789

Cemalcilar Z, Jensen C, Tosun J (2019) Gendered intergenerational transmission of work values? A country comparison. Ann Am Acad 682:125-138

Charles M (1992) Cross-national variation in occupational sex-segregation. Am Sociol Rev 57(4):483-502

Charles M (2003) Deciphering sex segregation: vertical and horizontal inequalities in ten national labor markets. Acta Sociol 46:267-286

Charles M, Grusky DB (2004) Occupational Ghettos: The Worldwide Segregation of Men and Women. Stanford University Press, Stanford

Chesters J (2009) Household structure and housework hours: the effect of women's changing labour force participation on the domestic division of labour. PhD Thesis, The University of Queensland, Australia. https://www.espace.library.uq.edu.au/view/UQ:188804

Chesters J (2015) Does migrant status affect educational achievement, aspirations and attainment? Multicult Educ Rev 7(4):197-212

Chesters J (2021) Gender attitudes and occupational aspirations in Germany: Are young men prepared for the jobs of the future? Work Employ Soc. https://doi.org/10.1177/09500170211017046

Correll SJ (2017) Reducing gender biases in modern workplaces: A small wins approach to organizational change. Gend Soc 31(6):725-750

Davis SN, Greenstein TN (2009) Gender ideology: components, predictors, and consequences. Annu Rev Sociol 35:87-105

Ebner C (2015) Labour market developments and their significance for VET in Germany: An overview. Res Comp Int Educ 10(4):576-592

England P, Allison P, Wu X (2007) Does bad pay cause occupations to femininze, does feminization reduce pay, and how can we tell with longitudinal data? Soc Sci Res 36:1237-1256

Estevez-Abe M (2005) Gender bias in skills and social policies: The varieties of capitalism perspective on sex segregation. Soc Polit 12(2):180-215

Estevez-Abe M (2006) Gendering The varieties of capitalism: A study of occupational segregation by sex in advanced industrial societies. World Polit 59(1):142-175

Garcia-Mainar I, Montuenga VM, Garcia-Martin G (2018) Occupational prestige and gender-occupational segregation. Work Employ Soc 32(2):348-367 
Gauchat G, Kelly M, Wallace M (2012) Occupational gender segregation, globalization, and gender earnings inequality in U.S. metropolitan areas. Gend Soc 26(5):718-774

Glaesser J, Cooper B (2011) Selectivity and flexibility in the German secondary school system: A configurational analysis of recent data from the German socio-economic panel. Eur Sociol Rev 27(5):570-585

Haasler SR (2014) The impact of learning on women's labour market transitions. Res Comp Int Educ 9(3):354-369

Haasler SR, Gottschall K (2015) Still a perfect model? The gender impact of vocational training in Germany. J Vocat Educ Train 67(1):78-92

Hadjar A, Aeschlimann B (2015) Gender stereotypes and gendered vocational aspirations among Swiss secondary school students. Educ Res 57(1):22-42

Hagglund AE, Bachmann A-C (2017) Fast lane or down the drain? Does the occupation held prior to unemployment shape the transition back to work? Res Soc Stratif Mobil 49:32-46

Jacob M, Kleinert C, Kühhirt M (2013) Trends in gender disparities at the transition from school to work: labour market entries of young men and women between 1984 and 2005 in West Germany. J Vocat Educ Train 65(1):48-65

Jarman J, Blackburn RM, Racko G (2012) The dimensions of occupational gender segregation in industrial countries. Sociology 46(6):1003-1019

Kalleberg A (2011) Good Jobs, Bad Jobs: The Rise of Polarized and Precarious Employment Systems in the United States, 1970s-2000s. Russell Sage Foundation, New York

Kmec JA (2005) Setting occupational sex segregation in motion: Demand-side explanations of sex traditional employment. Work Occup 32(3):322-354

Koskinen Sandberg P, Tornroos M, Kohvakka R (2018) The institutionalised undervaluation of women's work: the case of local government sector collective agreements. Work Employ Soc 32(4):707-725

Leuze K, Strauss S (2016) Why do occupations dominated by women pay less? How 'female-typical' work tasks and working-time arrangements affect the gender wage gap among higher education graduates. Work Employ Soc 30(5):802-820

Lueptow LB, Garovich-Szabo L, Lueptow MB (2001) Social change and the persistence of sex typing: 1974-1997. Soc Forces 80(1):1-36

Malin L, Jacob M (2019) Gendered occupational aspirations of boys and girls in Germany: the impact of local VET and labour markets. J Vocat EducTrain 71(3):429-448

McGinn KL, Castro MR, Lingo EL (2019) Learning from mum: Cross national evidence linking maternal employment and adult children's outcomes. Work Employ Soc 33(3):374-400

Nentwich JC, Kelan EK (2014) Towards a typology of "Doing Gender" An analysis of empirical research and its challenges. Gend Work Organ 21(2):121-134

Reskin BF (1993) Sex segregation in the workplace. Annu Rev Sociol 19:241-270

Ridgeway CL, Correll SJ (2004) Unpacking the gender system: A theoretical perspective on gender beliefs and social relations. Gend Soc 18(4):510-531

Ridgeway CL, Backor K, Li YE, Tinkler JE, Erickson KG (2009) How easily does a social difference become a status distinction? Gender Matters. Am Sociol Rev 74:44-62

Skopek J, Pink S, Bela D (2013) Starting Cohort 4: 9th grade (SC4) SUF Version 1.1.0 Data ManualNational Education Panel Study (NEPS). University of Bamberg, Bamberg

Webb J (2009) Gender and occupation in market economies: change and restructuring since the 1980s. Soc Polit 16(1):82-110

West C, Fenstermaker S (1993) Power, inequality and the accomplishment of gender: An ethnomethodological view. In: England P (ed) Theory on Gender/Feminism on Theory. Aldine de Gruyter, New York, pp 151-174

West C, Zimmerman DH (1987) Doing gender. Gend Soc 1(2):125-151 